\title{
Majoid Crabs Community (Crustacea: Decapoda) from Infralittoral Rocky/sandy Bottom of Anchieta Island, Ubatuba
}

\author{
Fernando L. Mantelatto ${ }^{1 *}$, Fabíola C. R. Faria ${ }^{1}$, Renata Biagi ${ }^{1}$ and Gustavo A. S. Melo ${ }^{2}$ \\ ${ }^{1}$ Departamento de Biologia; FFCLRP; Universidade de São Paulo - USP; Av. Bandeirantes, 3900; 14040-901; \\ Ribeirão Preto - SP - Brazil. ${ }^{2}$ Museu de Zoologia; USP; Av. Nazareth, 481; C. P. 7172-01051; São Paulo - SP - \\ Brazil
}

\begin{abstract}
The aim of the present study was to characterize the composition of Majoidea crabs inhabiting the infralittoral rocky/sandy bottom of Anchieta Island (Ubatuba), from north coast of São Paulo State. Crabs were collected monthly during 1999 and 2000 by using SCUBA and cages. The occurrence of eight species of majoids (Epialtus brasiliensis, Mithraculus forceps, Mithrax braziliensis, Mithrax hispidus, Mithrax tortugae, Pelia rotunda, Pitho lherminieri and Stenorhynchus seticornis) was registered and corresponded to $24.2 \%$ of total of majid crabs recorded in the coast of São Paulo State. Mithraculus forceps, Mithrax tortugae and Stenorhynchus seticornis were most abundant in samples and constituted populations that belonged to the brachyuran community of the studied area. The taxocoenosis of the area was dominated by M. forceps (57.62\%). The occurrence of Mithrax braziliensis in the present study enlarged its south distribution to the São Paulo State.
\end{abstract}

Key words: Brachyura, majoidea, diversity

\section{INTRODUCTION}

Studies on regional checklists are of great importance for the development of preservation policy, because these studies lead to the best comprehension of structure, functioning and variability of communities ecology (Fransozo et al., 1992; Hebling et al., 1994), beyond to serve as a base for biodiversity studies on zoogeographic regions or provinces in specific habitats (Hendrickx and Harvey, 1999). In particular, the insular ecosystem requires specific standard of preservation and exploration (Angelo, 1989), because it shelters peculiar and fragile communities. Moreover, the knowledge of these communities may contribute to the elucidation of evolution, speciation and distribution problems with respect to marine species (MacArthur, 1972). The northern coast of the São Paulo State is considered an important area for crustacean investigations, with approximately 58\% of crab species recorded for the Brazilian coast registered for this area (Melo, 1996). Surveys of this northern coast brachyuran fauna along the last ten years were conducted primarily with trawls in nonconsolidate bottom areas. However, Brachyura associated with hard substrates, especially in infralittoral areas, received little attention.

The Majoidea super-family (see Hendrickx, 1999 and Martin and Davis, 2001 for systematic update)

* Author for correspondence 
constitutes the high number brachyuran species described for the South Atlantic (83), which about $50 \%$ have been recorded on the coast of São Paulo State (Pohle et al., 1999). Majid species occupy rocky shores, sand flats, rocks, seaweed beds and corals among others, and is one of the most diverse brachyuran groups, with approximately 900 species worldwide (Negreiros-Fransozo and Fransozo, 2001). Moreover, they constitute an important group of true crabs for phylogenetic studies (Marques and Pohle, 1998), mainly because of the presence of two stages of zoea during postembryonic development (Pohle et al., 1999).

The present study was undertaken to describe an uninvestigated community of the majoids living on the infralittoral rock/sandy area of Anchieta Island, north coast of São Paulo State. This report provides a checklist of crabs and some information on reproductive aspects and abiotic factors as a long-term effort to the knowledge of the dynamic of brachyuran community in this area.

\section{MATERIAL AND METHODS}

\section{Study Area}

Anchieta Island $\left(23^{\circ} 33^{\prime} \mathrm{S}\right.$ and $\left.45^{\circ} 05^{\prime} \mathrm{W}\right)$ is the second largest island of the north coast of São Paulo State. This island has been affected by anthropogenic activities such tourism and fishery resources and in 1977 have been declared an ecological reserve of São Paulo State. The physical and chemical features of the area have been described by Oliveira (1983) and Medeiros (1992). However, scientific information about the crustacean fauna is sparse, and among the available reports are the studies of Forneris (1969) about general fauna of invertebrates from soft bottom and Hebling et al. (1994) and Mantelatto and Garcia (2002) on hermit crab fauna from nonconsolidate and rocky shore substrates, respectively.

\section{Sampling and Analysis}

The crabs were obtained monthly over a period of two years (from January 1999 to December 2000) in the infralittoral rocky/sandy area of Anchieta Island, whose surface is irregular, with many huge boulders. Previous diving observations indicated some areas favorable for the study, but turbid water and sea conditions (waves and wind) did not permit routine collecting in the same area month by month. Specimens were captured during the daytime by three persons using SCUBA diving methods over a period of $20 \mathrm{~min}$ over an area of about $850 \mathrm{~m}^{2}$. Additional data were obtained from cages $(25 \times 25 \times 25 \mathrm{~cm}$ with $1 \mathrm{~mm}$ net) that were installed in the infralittoral area of Praia do Leste on November and December 2000. The cages (5 per month) were kept on substrate for $20 \pm 5$ days/month. This methodology allowed the capture of diverse small crabs and all the majoids captured in these cages were included in the analysis of the faunistic composition (occurrence), but not in the ecological coefficients utilized for analysis since they are present in the area and were not collected by SCUBA. After collection, the animals were frozen and transported to the laboratory where they were fixed in $70 \%$ alcohol for later analysis. The crabs were identified, sexed, and recorded the ovigerous condition.

The Shannon-Wiener Diversity index (Shannon and Weaver, 1963): $\mathrm{H}^{\prime}=-\sum_{\mathrm{i}=1}^{\mathrm{s}} P i \cdot \log _{2} P i$, where "s" is the number of species and "Pi" is the proportion of individuals of the species i; the Evenness index ( $\mathrm{J}$ ') (Pielou, 1966): $\mathrm{J}^{\prime}=\mathrm{H}^{\prime} / \log _{2} \mathrm{~S}$ and the Constancy index (Cabioch, 1968; Dajoz, 1983): C=P.100/p, where "P" is the total number of samples belonging to a given species and "p" is the total number of samples analyzed, were calculated. Specimens were then classified into three different constancy categories: constant $(\mathrm{C} \geq 50 \%)$, accessory $(25 \%<\mathrm{C}$ $<50 \%)$ and accidental $(\mathrm{C} \leq 25 \%)$.

The reproductive period of the community was expressed as the percentage of females carrying eggs (ovigerous females) relative to the total number of females collected. To better visualize the results in terms of seasonal occurrence we grouped the monthly samples into summer (December, January and February), autumn (March, April and May), winter (June, July and August) and spring (September, October and November) samples. Some physical and chemical factors (depth, temperature and salinity) were estimated during the collections. Pearson analysis $(\mathrm{p}<0.05)$ was used to determine the association between these factors and the number of individuals.

\section{RESULTS}

A total of 118 specimens of majoids were collected (Table 1), compressing five families and 
six genera (Epialtidae: Epialtus; Mithracidae: Mithraculus and Mithrax; Pisidae: Pelia; Tychidae: Pitho and Inachidae: Stenorhynchus) represented by eight species: Epialtus brasiliensis Dana, 1852; Mithraculus forceps (A. Milne Edwards, 1875); Mithrax braziliensis Rathbun, 1892; Mithrax hispidus (Herbst, 1790), Mithrax tortugae Rathbun, 1920; Pelia rotunda A. Milne Edwards, 1875; Pitho lherminieri (Schramm, 1867), and Stenorhynchus seticornis (Herbst, 1788). The taxocoenosis in the studied area was dominated by $M$. forceps $(57.62 \%)$ that was the only species that occurred every sampled month (Table 1).

Table 1 - Number of individuals collected from 1999 to 2000 in Anchieta Island (CN = constancy: Co = constant; Ac = accessory; Ad = accidental)

\begin{tabular}{l|c|c|c|c|c|c|c|c|c|c|c|c|c|c}
\multicolumn{1}{c}{ Species } & Jan & Feb & Mar & Apr & May & Jun & Jul & Aug & Sep & Oct & Nov & Dec & CN & Total \\
\hline E. brasiliensis & - & - & - & - & - & - & - & - & - & - & - & $2 * *$ & - & 2 \\
M. forceps & 3 & $5^{*}$ & 4 & $4^{*}$ & $5^{*}$ & $5^{*}$ & - & $11^{*}$ & $2 *$ & $9 *$ & 6 & $14 *$ & Co & 68 \\
M. braziliensis & - & 1 & - & - & - & - & - & - & - & - & - & - & Ad & 1 \\
M. hispidus & 4 & - & - & - & - & - & - & - & - & - & - & - & Ad & 4 \\
M. tortugae & - & 1 & 4 & $1^{*}$ & 1 & 2 & - & - & - & 1 & - & - & Co & 10 \\
P. rotunda & - & - & - & - & - & - & - & - & - & - & - & $3 * *$ & - & 3 \\
P. lherminieri & - & $2 *$ & - & - & - & - & - & - & - & - & - & - & Ad & 2 \\
S. seticornis & $14 *$ & $5 *$ & $2 *$ & 1 & - & - & - & - & - & 2 & $1 *$ & 4 & Co & 29 \\
\multicolumn{1}{r}{ Total } & $\mathbf{2 1}$ & $\mathbf{1 4}$ & $\mathbf{1 0}$ & $\mathbf{6}$ & $\mathbf{6}$ & $\mathbf{7}$ & $\mathbf{0}$ & $\mathbf{1 1}$ & $\mathbf{2}$ & $\mathbf{1 3}$ & $\mathbf{7}$ & $\mathbf{2 3}$ & & $\mathbf{1 1 8}$ \\
\hline
\end{tabular}

*Occurrence of ovigerous females.

**Animals captured in cages.
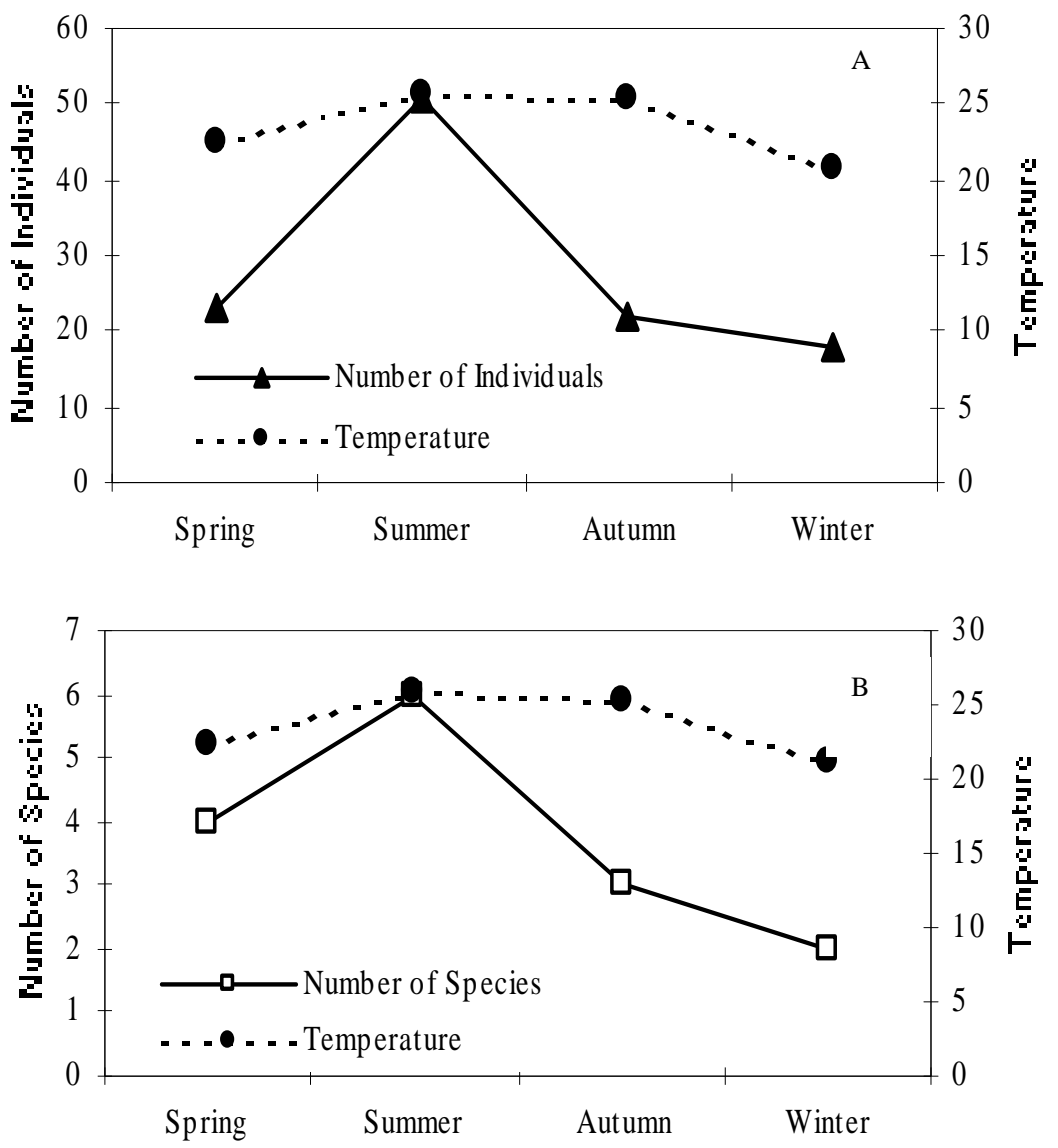

Figure 1 - Number of individuals (A) and species (B) collected in Anchieta Island in function of the temperature $\left({ }^{\circ} \mathrm{C}\right)$ during 1999 and 2000. 


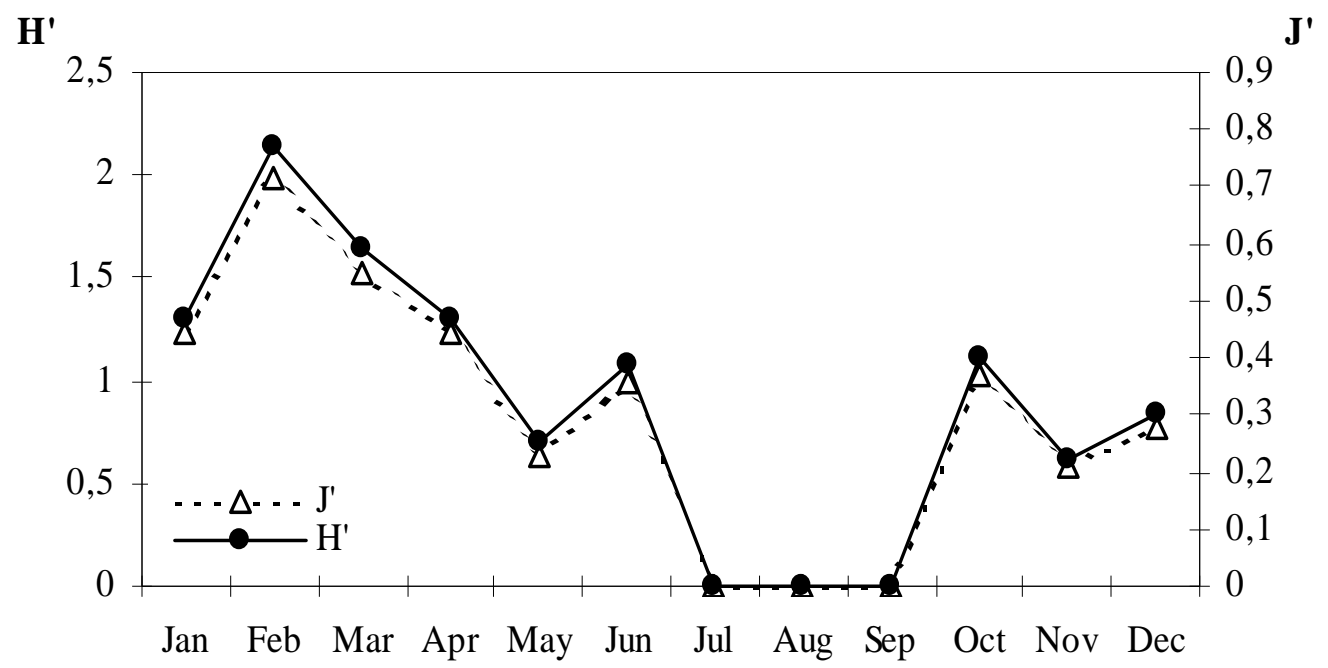

Figure 2 - Monthly oscillation of diversity $\left(\mathrm{H}^{\prime}\right)$ and equitability $\left(\mathrm{J}^{\prime}\right)$ during the study period (January 1999 to December 2000) in Anchieta Island.

Epialtus brasiliensis and $P$. rotunda were not considered in the analysis of composition, because they were collected by cages.

Regarding the pattern of temporal occurrence, $M$. forceps $(\mathrm{C}=91.6 \%), M$. tortugae $(\mathrm{C}=50 \%), S$. seticornis $(\mathrm{C}=58.3 \%)$ were considered constants; $M$. braziliensis, $M$. hispidus and P. lherminieri that presented $\mathrm{C}=8.3 \%$, were considered accidentals (Table 1). Positive and significant correlation $(\mathrm{p}<$ $0.05)$ was detected between: temperature $\mathrm{x}$ number of individuals $(r=0.67 ; \mathrm{p}=0.029)$, temperature $\mathrm{x}$ number of species $(\mathrm{r}=0.82 ; \mathrm{p}=0.0009)$; and negative correlation was observed between the number of species x salinity $(\mathrm{r}=-0.72 ; \mathrm{p}=0.008)$. Number of individuals and species presented the tendency to increase during the summer and decrease during autumn and winter (Fig. 1), showing close association between number of individuals and richness of species. The diversity and evenness index ranged from 0 to 1.99 and 0 to 0.77 respectively, reaching higher values in the summer $(1.33 \pm 0.61 ; 0.51 \pm 0.24)$ decreasing during the autumn $(1.13 \pm 0.45 ; 0.44 \pm 0.06)$ and winter $(0.33 \pm 0.57 ; 0.13 \pm 0.15)$ and increasing in the spring $(0.53 \pm 0.51 ; 0.21 \pm 0.37)$ (Fig. 2). It was observed a clear domain of $M$. forceps regarding the other species.

\section{DISCUSSION}

The present study revealed that the Anchieta Island sheltered a considerable number of species of majoid crabs, corresponding to $24.2 \%$ of the 33 species recorded for the São Paulo coast (Pohle et al., 1999). Considering the relatively small area of Anchieta Island compared to the range of the São Paulo coast, we considered that the diversity of majoids crabs was high. A high diversity was also recorded for the hermit crabs in this area (Mantelatto and Garcia, 2002) that could be related to the fact that this island constituted an habitat with favorable conditions to set up and reproduction of these animals.

The first record of occurrence of the $M$. braziliensis for São Paulo State increased its geographical distribution, which was restricted from Piauí to Rio de Janeiro (Melo, 1996). This fact has been observed for other crab and hermit crab species along the Brazilian coast, i.e. Eurypodius latreillei (Guérin, 1828) (Inachidae) and Coenophthalmus tridentatus (A. M. Edwards, 1879) (Portunidae) by Melo (1990); Mithrax tortugae by Tavares and Albuquerque (1993); Charybdis hellerii (A. M. Edwards, 1867) (Portunidae) by Mantelatto and Dias (1999); Mithrax hispidus by Rieger and Giraldi (2001); Dardanus venosus (H. Milne Edwards, 1848) (Diogenidae) by Mantelatto et al. (2001), reinforcing the importance of this type of study for 
the knowledge of fauna as well as for biogeographic and ecological studies.

Basing on the pattern of temporal occurrence we inferred that $M$. forceps, $M$. tortugae and $S$. seticornis constituted populations that belonged to the community of the studied area. Several factors are used to explain the occurrence of accidental species in a determined region (migration, accidental transport by fishery boat or introduced due to commercial importance). However, due to acquired experience along years of study in this region, these factors did not seem probable, but we did not discard them to explain the accidental presence of $M$. braziliensis, $M$. hispidus and $P$. lherminieri in this area. Therefore, it was more plausible to believe that $M$. braziliensis and $P$. lherminieri constituted small population in the area, and that the absence of these individuals in almost all month samplings could be related to the difficulty in collection, in view of the small size of the individuals and of the cryptic habit characteristic of majoids. In the case of $M$. hispidus it was possible that some migration of adults for other areas could occur, because these were not captured during the period of study, when were collected only juvenile specimens.

We believed that the cryptic habit of majoids could have influenced the pattern of seasonal occurrence observed in the present study. During summer (high temperature), the diversity, the evenness and the number of individuals of species were higher than in winter (low temperature). A similar pattern of occurrence of hermit crabs (Fransozo et al., 1998; Mantelatto and SouzaCarey, 1998; Mantelatto and Garcia, 2002) and brachyuran crabs (Fransozo et al., 1992; Hebling et al., 1994; Mantelatto and Corrêa, 1996; Mantelatto and Fransozo, 2000) was also observed in the Ubatuba region. In addition, CarmonaSuárez (2000) studying three Mithraculus species, i.e., M. forceps, M. coryphe (Herbst, 1801) and $M$. sculptus (Lamarck, 1818), from islets in the Morrocoy National Park (Venezuela) and Mantelatto et al. (2003) studying M. forceps population in the Anchieta Island, Ubatuba reported the same variation in seasonal occurrence of these animals.

Anchieta Island is affected by three water masses, with different distribution patterns in the summer and winter (Castro Filho et al., 1987). Coastal Water $(\mathrm{CW})$ has a high temperature and low salinity $\left(\mathrm{T}>20^{\circ} \mathrm{C}, \mathrm{S}<36\right)$, Tropical Water (TW) has both high temperature and salinity $\left(\mathrm{T}>20^{\circ} \mathrm{C}\right.$,
S > 36), and South Atlantic Central Water (SACW) has both low temperature and salinity (T $\left.<18{ }^{\circ} \mathrm{C}, \mathrm{S}<36\right)$ following an annual cycle. The dynamics of these currents is responsible for seasonal alterations of temperature, salinity and nutrient concentrations. The higher number of majoid individuals collected during the summer might have been influenced by the interaction of $\mathrm{CW}$ and SACW water masses. SACW is rich in nutrients and when it reaches shallow areas during the summer, primary production increases (Mantelatto and Fransozo, 2000). Consequently, more food should be channeled to the benthos in summer (Pires, 1992), making the habitat favorable for the growth and reproduction of benthic communities.

According to Mantelatto and Fransozo (2000), both brachyuran community composition and diversity are controlled, at least in part, by seasonal abundance of dominant species associated with monthly changes in environmental conditions. Intra- or interspecific factors (segregation of the sexes, competition, preypredator relationship, reproductive, and molt cycle, among others) could act to partition the resources of living space during a specific period when more food is available to adults or larvae (Mantelatto, 2000).

In the present study, it was observed that $M$. forceps dominated the structure and the dynamic of the majoid community from Anchieta Island. Carmona-Suárez (2000) reported on the dominance of $M$. forceps in relation to other species of Mithraculus community in two shelter regions in Morrocoy Island in Venezuela. This relationship of dominance was also found for other brachyurans by Fransozo et al. (1992), ManjónCabeza and García-Raso (1998) and Mantelatto and Fransozo (2000), and for anomurans by Mantelatto and Garcia (2002). Considering the abiotic influence on the species recorded in this study and based on the occurrence of ovigerous females, there existed evidence of a reproductive cycle concentrate in summer, corroborating the hypothesis of some authors that the reproductive period occurred during the warmer months (summer), being the temperature the more important factor. The evolution of ecological indices showed some variability, which suggested a community with variations in structure due to variations of abundance of a few species. 


\section{ACKNOWLEDGEMENTS}

The authors are grateful to FAPESP (Grant \# 98/07454-5) for financial support during the sampling work and CNPq for a Scientific Initiation Grant to FCRF (Proc. \# 109369/00-9), and for a Research Scholarships (PQ 300279/95-7 and 303224/87-8) to FLMM and GASM, respectively. We thank Secretaria do Meio Ambiente do Estado de São Paulo, IBAMA and Parque Estadual da Ilha Anchieta for permission (Proc. \# 42358/98) during the sampling work.

\section{RESUMO}

O objetivo do presente estudo foi caracterizar a composição dos caranguejos Majoidea habitantes do infralitoral rochoso/arenoso da Ilha Anchieta (Ubatuba), litoral norte do Estado de São Paulo. Os caranguejos foram coletados mensalmente durante 1999 e 2000, por mergulho autônomo e armadilhas. Foi registrada a ocorrência de oito espécies de caranguejos majóideos (Epialtus brasiliensis, Mithraculus forceps, Mithrax braziliensis, Mithrax hispidus, Mithrax tortugae, Pelia rotunda, Pitho lherminieri e Stenorhynchus seticornis) o que corresponde a $24,2 \%$ do total de majóideos registrados para o litoral do Estado de São Paulo. Mithraculus forceps, Mithrax tortugae e Stenorhynchus seticornis constituem populações frequentes na comunidade da área de estudo. A taxoeconose da área foi dominada por $M$. foreceps (57,62\%). A ocorrência de Mithrax braziliensis no presente estudo amplia sua distribuição sul para o Estado de São Paulo.

\section{REFERENCES}

Angelo, S. (1989), Ilhas do Litoral Paulista. São Paulo : Secretaria do Meio Ambiente.

Cabioch, L. (1968), Contribution a la convaissance des pleuplements benthipes de la Manobe Occidentale. Cah. Biol. Mar., 9, 493-720.

Carmona-Suárez, C. A. (2000), Differences between Mithraculus ssp. communities in exposed and sheltered shalow-water Thalassia beds in Venezuela. Crust. Issues, 12, 419-429.

Castro Filho, B. M.; Miranda, L. B. and Myao, S. Y. (1987), Condições hidrográficas na plataforma continental ao largo de Ubatuba: variações sazonais e em média escala. Bolm. Inst. Oceanogr., 35 : (2), 135-151.
Dajoz, R. (1983), Ecologia geral. São Paulo : Vozes, EDUSP.

Fransozo, A.; Negreiros-Fransozo, M. L.; Mantelatto, F. L.; Pinheiro, M. A. A. and Santos, S. (1992), Composição e distribuição dos Brachyura (Crustacea, Decapoda) do sublitoral não consolidado na Enseada da Fortaleza, Ubatuba (SP). Rev. Brasil. Biol., 52 : (4), 667-675.

Forneris, L. (1969), Fauna do sublitoral da Ilha Anchieta (23 $\left.32^{\prime} \mathrm{S}-45^{\circ} 04^{\prime} \mathrm{W}\right)$. Ciênc. Cult., 21 : (2), 449-450.

Fransozo, A. and Mantelatto, F. L. (1998), Population structure and reproductive period of the tropical hermit crab Calcinus tibicen (Decapoda: Diogenidae) in the region of Ubatuba, São Paulo, Brazil. J. Crust. Biol., 18 : (4), 738-745.

Hebling, N. J.; Mantelatto, F. L.; Negreiros-Fransozo, M. L. and Fransozo, A. (1994), Levantamento e distribuição de braquiúros e Anomuros (Crustacea, Decapoda) dos sedimentos sublitorais da região da Ilha Anchieta, Ubatuba (SP). Bolm. Inst. Pesca, 21, 1-9.

Hendrickx, M. E. (1999), Los cangrejos braquiuros (Crustacea: Brachyura: Majoidea y Parthenopoidea) del Pacífico Mexicano. CONABIO y Instituto de Ciencias del Mar y Limnología. Universidad Nacional Autónoma de México, México.

Hendrickx, M. E. and Harvey, A. W. (1999), Checklist of anomuran crabs (Crustacea: Decapoda) from the eastern tropical Pacific. Belg. J. Zool., 129, 363-389

MacArthur, R. H. (1972), Geographical ecology: patterns in distribution of species. New York : Harper and Row.

Manjón-Cabeza, M. E. and García-Raso, J. E. (1998), Structure and evolution of a Decapod crustacean community from the coastal detritic bottoms of Barbate (Cadiz, Southern Spain). J. Nat. Hist., 32, 1619-1630.

Mantelatto, F. L. (2000), Allocation of portunid crab Callinectes ornatus (Decapoda: Brachyura) in Ubatuba Bay, northern coast of São Paulo State, Brazil. Crust. Issues, 12, 431-443.

Mantelatto, F. L. and Corrêa, E. K. (1996), Composition and seasonal variations of the brachyuran crabs (Crustacea, Decapoda) living on Sargassum cymosum in the Ubatuba region, São Paulo, Brazil. Bioikos, 09-10 : (1/2), 22-31.

Mantelatto, F. L. and Souza-Carey, M. M. (1998), Brachyura (Crustacea, Decapoda) associated to Schizoporella unicornis (Bryozoa, Gymnolaemata) in Ubatuba Bay (SP), Brazil. Braz. Arch. Biol. Technol., 41 : (2), 212-217.

Mantelatto, F. L. and Dias, L. L. (1999), Extension of the known distribution of Charybdis hellerii (A. Milne-Edwards, 1867) (Decapoda, Portunidae) along the western tropical South Atlantic. Crustaceana, 72 : (6), 618-620. 
Mantelatto, F. L. and Fransozo, A. (2000), Brachyuran community in Ubatuba Bay, Northern coast of São Paulo State, Brazil. J. Shellfish Res., 19 : (2), 701-709.

Mantelatto, F. L. and Garcia, R. B. (2002), Hermit crab fauna from the infralitoral area of Anchieta Island (Ubatuba, Brazil). In: Briones, E. E. and F. Alvarez (eds). Modern Approaches to the Studies of Crustacean. pp. 137-144.

Mantelatto, F. L.; Biagi, R.; Martinelli, J. M. and Hebling, N. J. (2001), On record of Dardanus venosus ( $\mathrm{H}$. Milne Edwards) (Crustacea, Anomura) from the São Paulo State, Brazil. Rev. Bras. Zool., 18 : (1), 71-73.

Mantelatto, F. L.; Faria, C. R. and Garcia, R. B. (2003), Biological aspects of Mithraculus forceps (Brachyura, Mithracidae) from Anchieta Island, Ubatuba, Brazil. J. Mar. Biol. Assoc. U. K., 83 : (1/3), in press.

Marques, F. and Pohle, G. (1998), The use of structural reduction in phylogenetic reconstruction of decapods and phylogenetic hypothesis for 15 genera of Majidae testing previous larval hypothesis and assumptions. Invert. Reprod. Develop., 33 : (2/3), 241-262.

Martin, J. W. and Davis, G. E. (2001), An update classification of the recent Crustacea. Nat. Hist. Mus. Los Angeles, 39, 1-124.

Medeiros, L. R. A. (1992), Meio fauna de praia arenosa da Ilha Anchieta, São Paulo: I. Fatores físicos. Bolm. Inst. Oceanogr., 40, 27-38.

Melo, G. A. S. (1990), A presença, no litoral sudeste brasileiro, de espécies de Brachyura (Crustacea: Decapoda) originárias das regiões biogeográficas Megelânica e Argentina do Atlântico Sul. Atlântica, 12 : (2), 71-83.

Melo, G. A. S. (1996), Manual de Identificação dos Brachyura (caranguejos e siris) do Litoral Brasileiro. São Paulo : Plêiade.

Negreiros-Fransozo, M. L. and Fransozo, A. (2001), Larval development of Epialtus bituberculatus $\mathrm{H}$. Milne Edwards, 1834 (Crustacea: Decapoda: Brachyura: Majidae) with comments on majid larvae from the southwestern Atlantic. Proc. Biol. Soc. Wash., 114 : (1), 120-138.

Oliveira, M. M. A. (1983), Moluscos de praias da Ilha Anchieta (Ubatuba, São Paulo). Arq. Biol. Tecnol., 26 : (3), 383-390.

Pielou, E.C. (1966), The measurement of diversity in different types of biological collections. J. Theor. Biol., 13, 133-144.

Pires, A. M. S. (1992), Structure and dynamics of benthic megafauna on the continental shelf offshore of Ubatuba, Southerastern, Brazil. Mar. Ecol. Prog. Ser., 86, 63-76.
Pohle, G.; Mantelatto, F. L.; Negreiros-Fransozo, M. L. and Fransozo, A. (1999), Larval Decapoda (Brachyura). In: Boltovskoy, D. (ed.). South Atlantic Zooplankton. Leiden : Backhuys Publisher. pp. 1282-1351.

Rieger, P. J. and Giraldi, J. L. B. (2001). Mithrax hispidus (Herbst) e Mithrax tortugae Rathbun novos registros de Brachyura (Decapoda, Majidae) para o litoral de Santa Catarina, Brasil. Rev. Bras. Zool., 18 : (2), 653-654.

Shannon, C. E. and Weaver, W. (1963). The mathematical theory of communication. Urbana : University of Illinois Press.

Tavares, M. S. and Albuquerque, E. F. (1993), On the occurrence of Mithrax (Mithrax) tortugae Rathbun (Crustacea: Brachyura: Majidae) on the Brazilian continental shelf. Boln. Inst. Oceanogr. Venezuela, 27 : (1/2), 37-39.

Received: July 12, 2002; Revised: October 07, 2002; Accepted: March 15, 2003. 